\title{
Integration Pattern between Electrochemistry Competence with Battery Competence Unit and Analysis of Achievement Result of Creativity Indicator on Vocational High School
}

$1^{\text {st }}$ Inayah Rohmi

Magister of Science Education

Program SebelasMaret University

Jl. Ir. Sutami $36 A$

KentinganJebres Surakarta 57126, INDONESIA

ina.blitarian@gmail.com $2^{\text {nd }}$ Mohammad Masykuri

\author{
Magister of Science Education \\ Program SebelasMaret University \\ Jl. Ir. Sutami $36 A$ \\ KentinganJebres Surakarta 57126, \\ INDONESIA \\ mmasykuri@yahoo.com
}

\author{
$3^{\text {rd }}$ Endang Susilowati \\ Magister of Science Education \\ Program SebelasMaret University \\ Jl. Ir. Sutami $36 A$ \\ KentinganJebres Surakarta 57126, \\ INDONESIA \\ endwati@yahoo.com
}

\begin{abstract}
This study aims to: 1) determine the pattern of integration between electrochemistry competence and battery competence unit, 2) analyze the results of achievement of the indicator of creativity on the question of electrochemistry tests integrated with battery competence unit. The research was conducted in vocational school in Semarang regency. Data obtained through pretest and posttest in experimental class and conventional class. Pretest and posttest questions tested to students based on creativity indicators in vocational schools proposed by Piirto (2011) are: 1) cognitive strategies macroabilities (a) clarifying issues, conclusions, or beliefs, (b) analyzing or evaluating arguments, interpretations, beliefs, or theories, (c) generating or assessing solutionsand 2) cognitive strategies microskills (a) comparing and contrasting ideas, predictions, or interpretations, (b) making plausible inferences, predictions, or interpretations, (c) giving reason and evaluation evidence and alleged facts.The result of the integration pattern is the figure and matrix between electrochemistry competence and battery competence unit. Based on the results of the study showed that there is a increase in each indicator of creativity. The increase in each indicator of creativity in the experimental class is higher than conventional class.
\end{abstract}

Keywords- the integration pattern; modules; electrochemistry; creativity; vocational schools.

\section{INTRODUCTION}

Vocational High School is one secondary level of formal education that serves as a place to prepare learners to be ready in entering the world of work and able to compete in this era development challenge (Pratiwi A S, 2016).Vocational High School is a continuation of junior secondary education that has the main goal of preparing highly skilled, professional, and disciplined workforce in accordance with the demands of the world of work. This aims was contained in the 15th Law of National Educational System that mentioned the specific purpose of Vocational High School is preparing students to become productive human beings, able to work independently, filling job vacancies in the business world and the industry as a middle-level workforce in accordance with competencies in the skills program choose it. Vocational education is considered effective if it is a replica of the world of work, both in terms of the curriculum, the lesson plans, and the evaluation (Sukamto, 2001).

One of the problems in education is the weakness of the learning process. Learning is a process of interaction between teachers and students along with elements in it. Teachers are the most dominant factor that determines the quality of learning. The quality of good learning, will certainly produce good learning results as well(Wulandari, 2013). In the learning process students should be encouraged to develop thinking skills. The fact that happens in the process of learning in the classroom, students are only directed to the ability to memorize information.The lessons that the teacher presented lacked the challenge of students to think, consequently the students did not enjoy the lesson. Properly, the learning process is more concerned and the test results are the impact of the learning process.Teaching method and approach will determine the level of proficiency of students. Teachers should use student-centered approach to stimulate the students mind thus help students acquire and master the knowledge (Matanluk, Mohammad, Kiflee, \& Imbug, 2013).

Students with high creativity skills are significantly believed to have high academic ability in almost all subjects, and significantly also tend to continue in college (Baghetto, 2006). Creative thinking is divergent thinking which defined as 
producing a lot of varies idea about some topic in limited time(Chua, 2010; Guilford, 1968).Creative thinking involves creating something new or original. It involves the skills of flexibility, originality, fluency, imagery, associative thinking, attribute listing, metaphorical thinking and forced relationships. The aim of creative thinking is to stimulate curiosity and promote divergence (Anwar M N, Aness M, Khizar A, 2012). Creative thinking, one of the thinking skills, includes such skills like facilitating the individual's learning by the realization of his/her imagination, providing an opportunity for him/her to think, expressing his/her ideas easily and getting him/her to acquire new information (Ersoy, 2014).

Chemistry subjects as one of the subjects of basic interest in the field of expertise $(\mathrm{C} 1)$ that underlies the basic subjects of the skills program $(\mathrm{C} 2)$ and subjects of competence expertise (C3) as subjects that equip students to have work competence in accordance with Standard Competence of National Work of Indonesia (SKKNI) that has been determined by the Institute of professional certification that contains the competence to be mastered by students of Vocational High School in accordance with the prerequisites of work in the industrial world.Chemistry subjects ideally should be integrated in C2 subjects and especially C3 subjects and should be integrated also with a number of science and a number of learning activities provided to the students. Science and learning activities are given so that students are able to master a kind of work (Sukamto, 2001).

Based on observations that have been done show that some students difficulty in understanding the battery competence unit because in it involves chemistry processes and problems on how the battery work so that it needs to be developed electrochemistry module whose content is integrated directly with the subject matter competency skills. Electrochemistry competencies in chemistry subjects need to be developed in the form of integrated modules in the competency unit of testing, maintenance and replacement of battery batteries.Print learning resources such as modules are needed to support the success of learning and improve students' learning ability in learning.

The use of learning module is in line with constructivist learning strategies. Constructivism enables learners to construct their own understanding and knowledge of the world by experiencing things and reflecting on the experiences. This means that it deals with individuality, learner autonomy, and discovery learning. It has shifted emphasis, from teaching to learning, and it individualizes and contextualizes learner's knowledge construction and learning experiences. Furthermore, it makes learners take responsibility for their own learning as they are made to follow their own strategy of learning via the module (Rufii, 2015).
Thus the need for a study that refers to the source of learning, improvement of learning creativity that is integrated with the competencies of skills in Vocational High School of program of automotive engineering skills program.

\section{EXPEIMENTAL METHODS}

This study was used quantitative research method. Study data were analyzed with PretestPostest Control Group Design.

\section{A. Population and Study Sample}

The study was implemented in order to investigate creativity of students. Sample selection was made with purposive sampling. As a result, 71 students participated in the study with 35 students in experiment class and 36 students in conventional class. The participant attended was students class $\mathrm{X}$ of Vocational High School in Semarang Districtduring 2017-2018 academic years.

\section{B. Data Collection Instrument}

Data were obtained through pretest and postest in the experimental class and conventional class. Pretest and posttest questions tested to students based on creativity indicators in vocational schools proposed by Piirto (2011)are: 1) cognitive strategies macroabilities (a) clarifying issues, conclusions, or beliefs, (b) analyzing or evaluating arguments, interpretations, beliefs, or theories, (c) generating or assessing solutionsand 2) cognitive strategies microskills (a) comparing and contrasting ideas, predictions, or interpretations, (b) making plausible inferences, predictions, or interpretations, (c) giving reason and evaluation evidence and alleged facts. The learning in the experimental class uses the module based on PBL that has been developed, whereas in the conventional class it uses the lessons that the teacher usually does.

\section{RESULTS AND DISCUSSION}

The result of mapping the pattern of integration between electrochemistry competence and battery competence unit is shown in Figure 1.

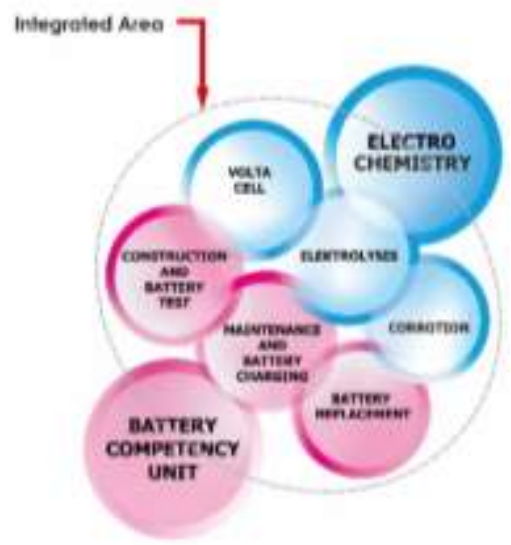

FIGURE 1. Pattern of integration of electrochemistry competenceand battery competence unit 
Based on the integration pattern shown in Figure 1, it can be described as follows:

1. Integrated voltaic cell with performance (practice) on sub competence of construction and battery testing

2. Electrolysis with performance (practice) on sub competence of maintenance and battery charging

3. Corrosion with performance (practice) on sub competence of battery replacement

The matrix between electrochemistry competence and performance (practice) on battery competence units is shown in Table 1. Based on Table 1 and Table 2 were resulted pattern integrated witch connected between sub competence with other subcompetence, show little conceptual change in understanding of integrated education are indications that the course has had a positive effect on students' willingness to integrate and their general skills related to practice (Haatainen \& Aksela, 2017).

Keep in mind that the integration can be different and not in line with each other. For example, the subject matter of a voltaic cell may be integrated with the sub-competence of caring for and charging the battery or with other sub-competencies. This is done to provide a more complex explanation and understanding on each subject.

The competency unit of battery testing, maintenance and replacement is a prequisite unit of competency which is in sequencing on the first subject, so that if the student does not understand the competency unit it will be difficult to learn the next competency unit. In chemistry subjects, electrochemistry competence enters the scope of the battery competence unit so that the coverage of the integrated material is essential to align the competency unit of testing, maintenance and replacement of the battery.

The electrochemistry competence contains the subject elements which are the prerequisite material for studying the competence unit of testing, maintenance and replacement of the battery. The module is intended for students of Automotive Engineering Skills Program, especially Automotive Light Vehicle Technique and Motorcycle Business Technique. Thus, it is expected that students of class $\mathrm{X}$ of SMK Program of Automotive Engineering Skills are able to understand the meaning of chemistry lesson in electrochemistry material with battery competence unit. In addition, students' creativity in learning is expected to be improved so that the objectives of the 2013 curriculum are to create personal and credible, productive, creative, innovative, and affective citizens.
TABLE 1. Matrix between electrochemistry competence and performance (practice) on battery

\begin{tabular}{|c|c|c|c|}
\hline $\mathrm{N}_{0}$ & $\begin{array}{c}\text { Electrochemistry } \\
\text { Competence }\end{array}$ & $\begin{array}{c}\text { Battery Competence } \\
\text { Unit } \\
\end{array}$ & Work Method (Practice) \\
\hline 1 & Volta cells & $\begin{array}{l}\text { Construction and } \\
\text { testing of batteries }\end{array}$ & Battery disassembly and testing \\
\hline 2 & Electrolysis & $\begin{array}{l}\text { Maintenance and } \\
\text { battery charging }\end{array}$ & Recharging the battery \\
\hline 3 & Corrosion & Battery replacement & $\begin{array}{l}\text { Observation of corrosion forms on the } \\
\text { battery and treatment it }\end{array}$ \\
\hline
\end{tabular}

TABLE 2.Illustration and steps practice of battery competence unit

\begin{tabular}{|c|c|c|c|}
\hline No & Work Method (Practice) & $\begin{array}{l}\text { Steps of practice } \\
\text { with creativity } \\
\text { indicator } \\
\text { (Piirto, 2011) }\end{array}$ & Illustration \\
\hline 1 & $\begin{array}{l}\text { Battery disassembly and } \\
\text { testing }\end{array}$ & $\begin{array}{l}\text { Construction and } \\
\text { testing of batteries : } \\
\text { a.Students analyzed } \\
\text { construction on } \\
\text { battery and } \\
\text { mention sparepart } \\
\text { and using it } \\
\text { b. Students were } \\
\text { clarificated result } \\
\text { testing of batteries } \\
\text { and compared with } \\
\text { manualbook }\end{array}$ & 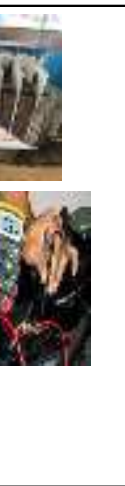 \\
\hline 2 & Recharging the battery & $\begin{array}{l}\text { Maintenance and } \\
\text { battery charging: } \\
\text { Students generating } \\
\text { or assessing solution } \\
\text { to recharge battery if } \\
\text { it was voltacedrop }\end{array}$ & \\
\hline 3 & $\begin{array}{l}\text { Observation of corrosion } \\
\text { forms on the battery }\end{array}$ & $\begin{array}{l}\text { Battery replacement: } \\
\text { Student observation of } \\
\text { battery, generating or } \\
\text { assessing solution to } \\
\text { treatment it and making } \\
\text { plausible from all steps on } \\
\text { practice battery } \\
\text { competence unit }\end{array}$ & \\
\hline
\end{tabular}

The results of the achievement of student creativity indicators obtained based on calculations on the experimental class and control class are shown in Figure 3. 


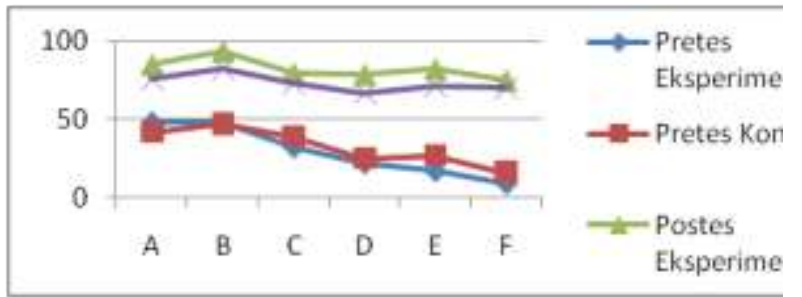

FIGURE 3.The Creativity Results Achievement

of Vocational High School

Information:

$\mathrm{A}=$ Giving reason and evaluation evidence and alleged facts

$\mathrm{B}=$ Analyzing or evaluating arguments, interpretations, beliefs, or theories

$\mathrm{C}=$ Comparing and contrasting ideals with actual practice

$\mathrm{D}=$ Making plausible inferences, predictions, or interpretations

$\mathrm{E}=$ Clarifying issues, conclusions, or beliefs

$\mathrm{F}=$ Generating or assessing solution

Based on the data presented in Figure 3 shows that there is an increase in each of the creativity indicators in the experimental class after using the modules based on PBL with each increase in indicators $\mathrm{A}$ to $\mathrm{F}$ as follows: $37.14 \%$; $45.71 \%$; $47.14 \%$; $56.43 \%$; $65 \%$, and $65.71 \%$. The highest percentage of achievement is on the indicators of constructing the solution. This means students can provide solutions to the problems provided by clarifying, identifying, and analyzing the problem. The lowest percentage of achievement is the indicator gives strong reasons based on the findings of the evaluation facts. This means that students are still weak in expressing the reasons based on facts related to the given material.

The increase in each creativity indicator in the control class with each increase in indicators $\mathrm{A}$ to $\mathrm{F}$ as follows: $34.03 \%$; 35.42\%; 34.03\%; $41.67 \%$; $44.44 \%$ and $54.17 \%$. The increase in each indicator of creativity in the experimental class is higher than that of the control class. This suggests that learning using electrochemistry modules based on PBL in battery competence units is more effective in improving student creativity than learning using teaching materials from schools.

Implementation of the learning process with the guidance of teachers, so that the impact on the implementation of PBL syntax that is integrated with the creativity of students can run well and obtained optimal results. Modules that have the potential to improve students' creativity is a problem-solving module one of which is a module-oriented model of Problem Based Learning (PBL) learning. Module based on Problem Based Learning (PBL) is a module characterized by the syntax of Problem Based Learning (PBL) learning proposed by Piirto (2011)which is to clarify issues, conclusions, or beliefs; analyze or evaluate arguments, interpretations, beliefs, or theories; build solutions; comparing ideas that are expected with real practice; make reasonable conclusions, predictions, or interpretations; and provide strong reasons based on the findings of the evaluation facts.

Based on the study of Gorghiu, G., Drăghicescu, L. M., Cristea, S., \& Gorghiu (2015)which states that PBL represents educational methods that use realworld problems such as important contexts for students to think creatively and achieve problemsolving skills. The quality of communication between teachers and students is very important, teachers become partners, and participants are active during the learning activities.

Learning is carried out with a goal to achieving competency standards. In order for the competency standards as learning objectives to be achieved effectively and efficiently teachers need to pay attention to the principles of learning. Teachers need to interact with students to learn more about things which is already known and thought by the students including things that have not been known by students. What competences are the bills in the learning should be discussed with the students so that the students are fully involved in understanding their position in the learning process of competence. Competency achievement map and module position map are very well used as a reference for planning discussion of learning implementation.

PBL also forms interpersonal skills: working in teams, teaching each other, serving customers, lead, negotiate, work well with people from different cultural backgrounds. PBL is well developed in Vocational High School relation to the development of Graduate Competence Standard.

\section{CONCLUSION}

Based on the research that has been done, we get the result of integration pattern in the form of picture and matrix between electrochemistry competence and battery competence unit. And shows that there is an increase in each indicator of creativity. The increase in each indicator of creativity in the experimental class is higher than that of the control class. This suggests that learning using PBL-based electrochemistry modules in battery competence units is more effective in improving student creativity than learning using teaching materials from schools.

\section{REFERENCES}

[1] Anwar M N, Aness M, Khizar A, N. M. and M. G. (2012). Relationship of Creative Thinking with the Academic Achievements of Secondary School Students. International Interdisciplinary Journal of Education, 1(3), 44-47.

[2] Baghetto, A. R. (2006). Creative Self-Efficacy: Correlates in Middle and Secondary Students. Creativity Research Journal, 18(4), 447-457.

[3] Chua, Y. P. (2010). Building a Test to Assess Creative and Critical Thinking Simultaneously. Procedia Social and Behavioral Sciences, 2, 551-559.

[4] Ersoy, E. and B. N. (2014). The Effects of ProblemBased Learning Method in Higher Education on Creative Thinking. 5th World Conference on Educational Sciences, 3(4), 94-98.

[5] Gorghiu, G., Drăghicescu, L. M., Cristea, S., \& 
Gorghiu, L. M. (2015). Problem-based Learning - An Efficient Learning Strategy in the Science Lessons Context. Procedia - Social and Behavioral Sciences, 1(19), 1865-1870.

[6] Guilford, J. P. (1968). Intellegence, Creativity, and Their Educational Implications. San Diego: Cal.

[7] Haatainen, O., \& Aksela, M. (2017). PRE-SERVICE CHEMISTRY TEACHERS LEARNING ABOUT INTEGRATED SCIENCE EDUCATION BY COLLABORATION AND CASE STUDY: TEACHING INTEGRATED SCIENCE EDUCATION TO PRE-, 2-4.

[8] Matanluk, O., Mohammad, B., Kiflee, D. N. A., \& Imbug, M. (2013). The Effectiveness of Using Teaching Module based on Radical Constructivism toward Students Learning Process. Procedia - Social and Behavioral Sciences, 90(InCULT 2012), 607-615. https://doi.org/10.1016/j.sbspro.2013.07.132

[9] Piirto, J. (2011). Creativity for 21st Century Skills: How to Embed Creativity into Curriculum. Ohio: Ashland
University.

[10] Pratiwi A S, S. D. A. and E. H. (2016). Contribution of Industrial Work Practice Performance and Creativeness to the Academic Skill and Its Effect to the Outcome of Skill Competency Test of Computer and Network Technology Skill Package in Vocational High School. Journal of Education and Vocational Research, 7(4), 31-36.

[11] Rufii, R. (2015). Developing Module on Constructivist Learning Strategies to Promote Students' Independence and Performance. International Journal of Education, 7(1), 18-28.

[12] Sukamto. (2001). Perubahan Karakteristik Dunia Kerja Dan Revitalisasi Pembelajaran Dalam Kurikulum Pendidikan Kejuruan. Yogyakarta: UNY press.

[13] Wulandari, B. (2013). Pengaruh Problem Based Learning Terhadap hasil Belajar Ditinjau dari Motivasi Belajar PLC di SMK. Jurnal Pendidikan Vokasi, 3(2), 178-191. 